University of Nebraska - Lincoln

DigitalCommons@University of Nebraska - Lincoln

January 1994

\title{
RADIOSENSITIVITY PARAMETERS FOR LETHAL MUTAGENESIS IN CAENORHABDITIS ELEGANS
}

\author{
F. A. Cucinotta \\ NASA Langley Research Center, Hampton, VA, francis.cucinotta@unlv.edu \\ J. W. Wilson \\ NASA Langley Research Center, Hampton, VA \\ Robert Katz \\ University of Nebraska-Lincoln, rkatz2@unl.edu
}

Follow this and additional works at: https://digitalcommons.unl.edu/physicskatz

Part of the Physics Commons

Cucinotta, F. A.; Wilson, J. W.; and Katz, Robert, "RADIOSENSITIVITY PARAMETERS FOR LETHAL MUTAGENESIS IN CAENORHABDITIS ELEGANS" (1994). Robert Katz Publications. 70.

https://digitalcommons.unl.edu/physicskatz/70

This Article is brought to you for free and open access by the Research Papers in Physics and Astronomy at DigitalCommons@University of Nebraska - Lincoln. It has been accepted for inclusion in Robert Katz Publications by an authorized administrator of DigitalCommons@University of Nebraska - Lincoln. 


\title{
RADIOSENSITIVITY PARAMETERS FOR LETHAL MUTAGENESIS IN CAENORHABDITIS ELEGANS
}

\author{
F. A. Cucinotta $†$, J. W. Wilson† and R. Katz \\ †NASA Langley Research Center \\ Hampton VA 23681-0002, USA \\ $\ddagger$ University of Nebraska \\ Lincoln, NE 68588-0111, USA
}

\begin{abstract}
For the first time track structure theory has been applied to radiobiological effects in a living organism. Data for lethal mutagenesis in Caenorhabditis elegans, obtained after irradiation with nine different types of ions of atomic number $1-57$ and gamma rays have yielded radiosensitivity parameters $\left(E_{0,} \sigma_{0}, k, m=68, G y\right.$, $\left.2.5 \times 10^{-9} \mathrm{~cm}^{2}, 750,2\right)$ comparable with those found for the transformation of C3HT10 1/2 cells $\left(180 \mathrm{~Gy}, 1.15 \times 10^{-10}\right.$ $\left.\mathrm{cm}^{2}, 750,2\right)$ but remote from those $\left(\mathrm{E}_{o}\right.$ and $\left.\sigma_{o}=\approx 2 \mathrm{~Gy}, \approx 5 \times 10^{-7} \mathrm{~cm}^{2}\right)$ for mammalian cell survival.
\end{abstract}

\section{INTRODUCTION}

The nematode Caenorhabditis elegans ( $C$. elegans) is currently under study ${ }^{(1-3)}$ as a model radiobiological system, including an investigation of gene mutations from exposure to galactic cosmic radiation. Nelson ${ }^{(2,3)}$ has reviewed several of the properties of $C$. elegans that favour their use in understanding the biological properties of heavy charged particles, especially for genetic processes, and their mutagenesis rates have been measured for several heavy ion beams ${ }^{(3)}$. Experimental data for ion and photon production of recessive lethal mutations in $C$. elegans are considered in order to obtain response parameters for the description of this endpoint in the track structure model. This is the first time the track structure model has been used for an animal system.

\section{TRACK STRUCTURE MODEL}

The cellular track model of Katz et al ${ }^{(4-6)}$ attributes biological damage from energetic ions to secondary electrons (delta rays) produced along the ion's path. The effects caused by energetic ions are correlated with those of gamma rays by assuming that sensitive sites near the ion's path are part of a larger system irradiated with gamma rays at the same dose, and are then studied through the radial dose distribution. The response due to ion effects is then determined by knowledge of the gamma ray response and the delta ray dose surrounding the ion's path. For a multitarget response with target number $\mathrm{m}$, the inactivation of cells is assumed to follow a Poisson distribution reflecting the random accumulation of sublethal damage with a radiosensitivity parameter $E_{0}$. The target number refers to the number of sensitive sites which must be damaged for the response to occur.
For the inactivation of celis by ions, two modes are identified: 'ion-kill' which corresponds to intratrack effects and 'gamma-kill' which corresponds to intertrack effects. Here the ion-kill mode describes the single particle inactivation with cross section $\sigma$. The inactivation cross section for a sensitive site is:

$$
\sigma=\int_{0}^{\infty} 2 \pi t d t\left(1-\mathrm{e}^{-\overline{\mathrm{D}} / \mathrm{E}_{0}}\right)^{\mathrm{m}}
$$

where $\bar{D}$ is the average dose at the sensitive site at radical distance $t$ from the ion's delta rays. The description of cell damage is separated by Katz et al into a so-called grain count regime, where inactivation occurs randomly along the path of the particle, and into the so-called track width regime, where many inactivations occur to sensitive targets not intersected by the particles path, and are said to be distributed like a hairy rope'. In the grain count regime, $\sigma$ may be parameterised as

$$
\sigma=\sigma_{0}\left(1-\mathrm{e}^{\left.-\mathrm{z}^{* 2 / \kappa \beta^{2}}\right)^{m}}\right.
$$

where $\sigma_{0}$ is the plateau value of the cross section and $\beta$ is the ion velocity. The effective charge number is given by

$$
Z^{*}=Z\left(1-e^{-125 \beta / Z^{2 / 3}}\right)
$$

and $k$ is a parameter related to the radius of the sensitive site $a_{0}$ (within the nucleus of a cell) by

$$
\mathrm{E}_{0} \mathrm{a}_{0}^{2} / \mathrm{k} \cong 2 \times 10^{-7} \mathrm{erg} \cdot \mathrm{cm}^{-1}
$$

The transition from the grain count regime to the track width regime is observed to take place at a value of $Z^{* 2} / \kappa \beta^{2}$ of about 4 . At lower values we are in the grain count regime and at higher values the track width regime.

The fraction of cells damaged in the ion-kill mode is $P=\sigma / \sigma_{0}$. Note that in the track width 


\section{F. A. CUCINOTTA, J. W. WILSON and R. KATZ}

regime $\sigma>\sigma_{0}$, and it is assumed that $P=1$. The track model assumes that a fraction of the ion's dose $(1-P)$ acts cumulatively with that for other particles in the gamma-kill mode. The mutated fraction of an initial cellular population $\mathrm{N}_{0}$, whose response parameters are $m, E_{0}$, and $\kappa$ or $a_{0}$ after irradiation by a fluence of particles $F$ is then written

$$
M=1-\Pi_{i} \times \Pi_{\psi}
$$

where

$$
\Pi_{i}=\mathrm{e}^{-\sigma F}
$$

is the ion-kill probability and

$$
\Pi_{\gamma}=1-\left(1-\mathrm{e}^{-D_{\gamma} E_{0}}\right)^{m}
$$

is the gamma-kill probability. The gamma-kill dose fraction is

$$
\mathrm{D}_{\gamma}=(1-\mathrm{P}) \mathrm{D}
$$

where $D$ is the absorbed dose. The track structure model is next applied to evaluate mutation rates from charged particles.

\section{RESPONSE PARAMETERS FOR RECESSIVE LETHAL MUTATIONS}

Caenorhabditis elegans contains a relatively small, fixed number of cells with only six pairs of chromosomes. Many of its genes have been identified and mapped. Testing procedures for several types of mutations have been developed ${ }^{(3,7)}$. Mutation response parameters for recessive lethal mutations are evaluated by fitting the data of Nelson et $a^{(3)}$, which were obtained with ion beams from the BEVALAC accelerator. The response to gamma rays, measured ${ }^{(3.7)}$ in the range 5-30 Gy, is well represented by Equation 7 with $\mathrm{m}=2$ and

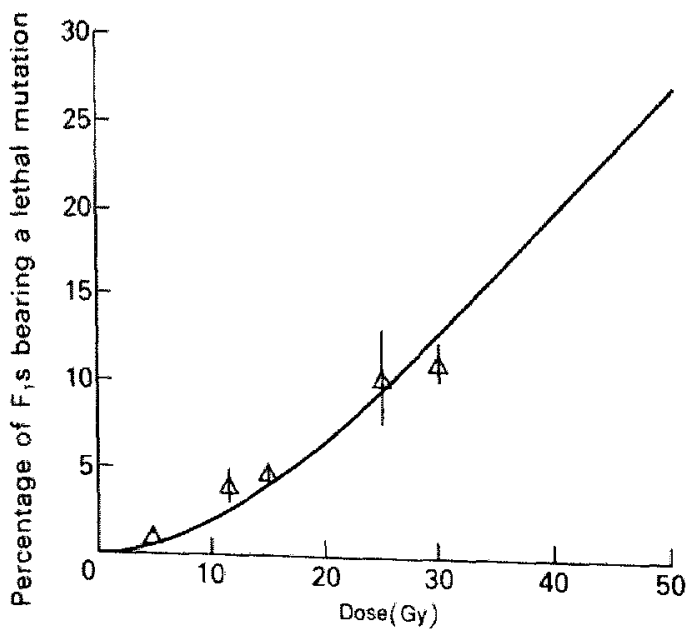

Figure 1. Petcentage of mutations in $C$. elegants versus gamma ray dose. Data from Nelson et al ${ }^{(3)}$.
$\mathrm{D}_{0}=68 \mathrm{~Gy}$, as shown in Figure 1. These parameters are chosen after considering the entire set of data, including both gamma ray and charged particle data.

The plateau value of the action cross section for recessive lethal mutations is seen to be near $0.2 \mu \mathrm{m}^{2}$ from the data ${ }^{(3)}$. The fitted value of $\sigma_{0}$ is $0.25 \mu \mathrm{m}^{2}$. The parameter $\kappa$ is found to be 700 . With these four parameters the measured rates are compared with the calculated mutation rates in Figures 2-4, using linear scales. All data are reproduced to within a factor 2 or better. In evaluating these radiosensitivity parameters some experimental data were neglected, especially when

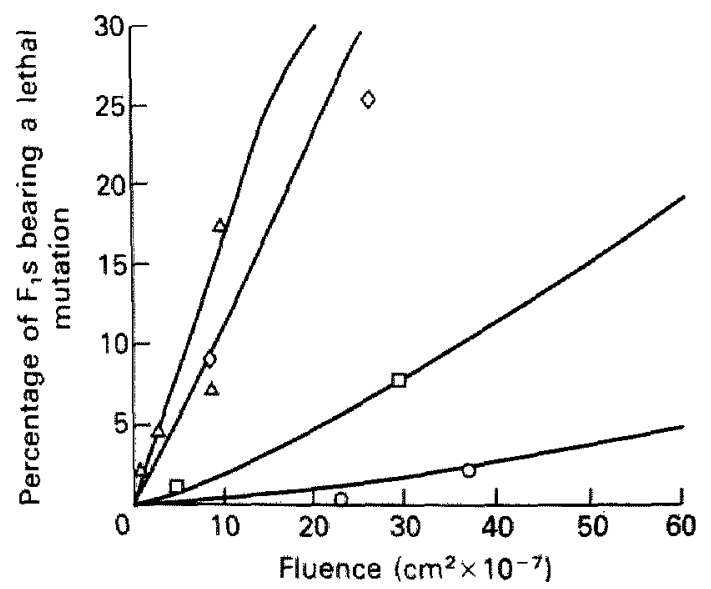

Figure 2. Percentage of mutations in $C$. elegans versus ion fluence for several ions. Data from Nelson et al ${ }^{(3)}$.

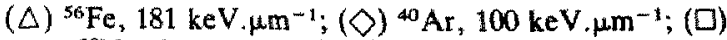
${ }^{20} \mathrm{Ne}, 31 \mathrm{keV}, \mu \mathrm{m}^{-1} ;(0){ }^{12} \mathrm{C}, 13 \mathrm{keV}, \mu \mathrm{m}^{-1}$.

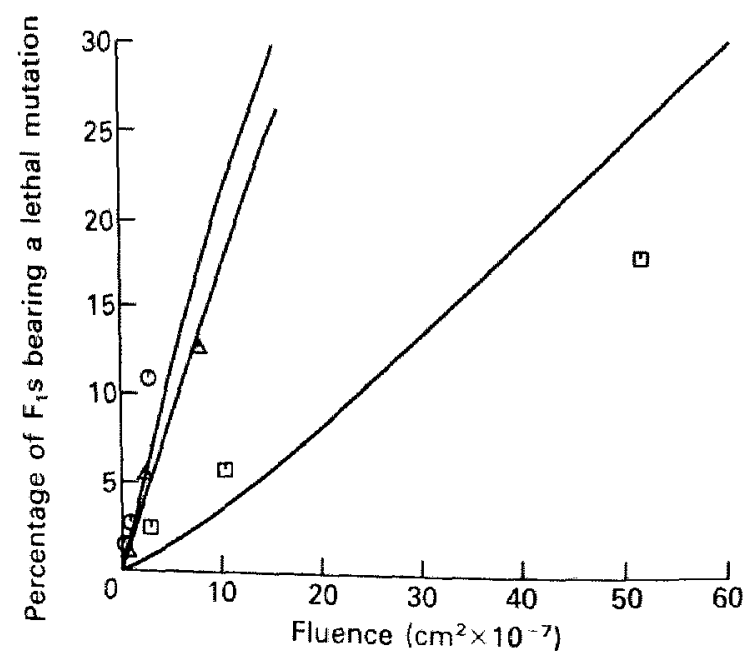

Figure 3. Percentage of mutations in $C$. elegans versus ion fluence for several other ions. Data from Nelson

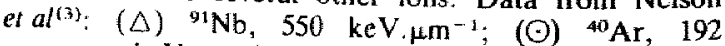
$\mathrm{keV} . \mu \mathrm{m}^{-1}$; (口) ${ }^{28} \mathrm{Si}, 49 \mathrm{keV} \cdot \mu \mathrm{m}^{-1}$. 


\section{LETHAL MUTAGENESIS IN CAENORHABDITIS ELEGANS}

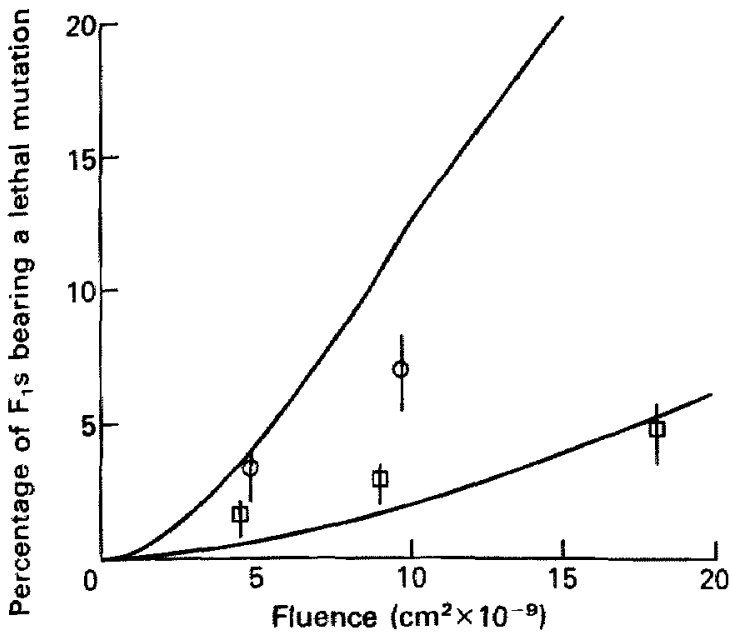

Figure 4. Percentage of mutations in $C$. elegans versus ion fluence for low LET ions. Data from Nelson et $a^{(3)}$.

(D) ${ }^{1} \mathrm{H}, 0.55 \mathrm{keV} . \mu \mathrm{m}^{-1}$; (O) ${ }^{4} \mathrm{He}, 1.8 \mathrm{keV} . \mu \mathrm{m}^{-1}$. the data were obtained with ion beams close to the Bragg peak since fragmentation and other effects complicate the comparisons of theory with experiment.

All earlier applications of track theory to radiobiology have been made with data obtained with molecules (enzymes, viruses, DNA) and cells. These data are the first application to an organism. It is gratifying that the four parameter model applies even to lethal mutations in an organism, and that the numerical values of the parameters obtained here are not inconsistent with those obtained from the analysis of mutations and transformations of cells is of interest. Hopefully radiobiologists concerned with fundamental mechanisms will take note of these results.

\section{ACKNOWLEDGEMENT}

Robert Katz is supported by the US Department of Energy and by NASA Grant No. NAG-1-1447.

\section{REFERENCES}

1. Coohill, T., Marshall, T., Schubert, W. and Nelson, G. Ultraviolet Mutagenesis of Radiation Sensitive (RAD) Mutants of the Nematode Caenorhabditis Elegans. Mutat. Res. 209, 99-106 (1988).

2. Nelson, G. A. Radiation Biology of HZE Particles. In: 41 st Congress of the Int. Astronautical Federation, Dresden, GDR, 6-12 October 1990, (IAA-90-548) (Paris: International Astronautical Federation).

3. Nelson, G. A., Schubert, W. W., Marshall, T. M., Benton, E. R. and Benton, E. V. Radiation Effects in Caenorhabditis Elegans, Mutagenesis by High and Low LET lonizing Radiation. Mutat. Res. 212, 181-192 (1989).

4. Katz, R., Ackerson, B., Homayoonfar, M. and Sharma, S. C. Inactivation of Cells by Heavy Ion Bombardment. Radiat. Res. 47, 402-425 (1971).

5. Katz, R., Sharma, S. C. and Homayoonfar, M. The Structure of Particle Tracks. In: Topics in Radiation Dosimetry, Supplement 1, Ed. F. H. Attix (New York: Academic Press) pp. 317-383 (1972).

6. Waligorski, M. P. R., Sinclair, G. L. and Katz, R. Radiosensitivity Parameters for Neoplastic Transformations in C3HIOTI/2 Cells. Radiat. Res. 111, 424-437 (1987).

7. Rosenbluth, R. E., Cuddenford, C. and Baillie, D. L. Mutagenesis in C. Elegans, L. A. Rapid Eukaryotic Mutagen Test System Using the Reciprocal Translocation etl (III, V). Mutat. Res. 110, 39-48 (1983). 